\title{
GENETIC BACKGROUND OF CONFORMATION DEFECTS IN POLISH BLACK-AND-WHITE HOLSTEIN-FRIESIAN BULLS - ANALYSIS OF PHENOTYPIC DISTRIBUTION*
}

\author{
Piotr Topolski ${ }^{1}$, Wojciech Jagusiak ${ }^{2}$ \\ ${ }^{1}$ Department of Animal Genetics and Breeding, National Research Institute of Animal Production, \\ 32-083 Balice n. Kraków, Poland \\ ${ }^{2}$ Department of Genetics and Animal Breeding, University of Agriculture, Al. Mickiewicza 24/28, \\ 30-059 Kraków, Poland
}

\begin{abstract}
Phenotypic distribution of 22 routinely evaluated conformation defects was analysed in a population of Polish Black-and-White Holstein-Friesian bulls, sired by different males. Some variation was observed in mean frequency of different morphological defects and in their severity. Large differences were found in frequency of conformation defects and in their number between groups of half-brothers. The most common defects in the bull population analysed were two types of leg defects: wide interdigital space and soft pasterns, which occurred in 199 and 70 animals, respectively. Wide interdigital space was most frequent in 4 groups of half-brothers, in which this defect affected more than $25 \%$ of the bulls. The least common defects were the defects of external genitalia, which were found in single animals. The only defect that did not occur was that of testes. The statistical significance of the phenotypic distributions obtained for bull conformation defects was confirmed using the chi-square test of independence and the Fisher-Yates exact test.
\end{abstract}

Key words: defective type characteristics, sire, Holstein-Friesian

In many countries, including Poland, the recording of external conformation defects has become an integral part of routine assessment of type and conformation in dairy cattle (Brotherstone et al., 1990; Principles of Danish Cattle Breeding, 1999; Wang et al., 2002).

The Polish programme for conformation assessment of Polish Black-and-White Holstein-Friesian bulls accounts for 22 conformation defects in addition to descriptive traits, detailed traits and one measurable trait (rump height). These traits are scored separately but are related to descriptive conformation traits and thus influence the overall score (KCHZ, 2002).

*This study was finansed from statutory activity, project no. 01-1.10.1. 
Like conformation of cattle (Boettcher et al., 1998), conformation defects are associated with length of productive life (Wang et al., 2002).

According to most studies, descriptive and detailed scores for type and conformation traits are linearly related to variously defined survival traits, with nonoptimal values of conformation traits being conducive to earlier culling (Sewalem et al., 2004; Buenger et al., 2001; Caraviello et al., 2004). In this respect, the authors cited above found particularly unfavourable relationships between longevity (survival) and three groups of conformation traits that include structure of udder, legs and feet, and rump. Similarly, the conformation defects of these body parts are an important reason for early culling of cattle. Wang et al. (2002) found only unfavourable genetic correlations between this group of traits and length of productive life.

The incidence of conformation defects in the Polish population of bulls is only recorded and serves to provide a more detailed description of the animals evaluated. With regard to individual animals, they provide the breeder with direct selection information that is only used as a phenotypic source of information.

A search of the specialist literature reveals no studies on the genetic background of conformation defects in Holstein-Friesian bulls. The few studies in this area cover only the female population*. Considering the priority given to sire paths in dairy cattle selection programmes, in particular the sire-son pathway, it is appropriate to subject the Polish population of breeding bulls to these analyses.

Studying the mechanism of trait inheritance through comparative analysis of the distribution of parent and offspring phenotypes is the basic method of acquiring information on the genetic background of these defects.

The objective of the study was to analyse the incidence of conformation defects in a population of Polish Holstein-Friesian bulls sired by different males.

\section{Material and methods}

The study used a set of data on conformation defects of 3691 Polish Blackand-White Holstein-Friesian bulls, evaluated in the years 2002-2008. This set contains pedigree information and scores for 22 conformation defects, classified into 6 groups: front, middle, back, rump, legs, and external genitalia. The morphological defects are recorded in three categories $(0-$ no defect, 1 - minor defect, 2 - serious defect).

Statistical analyses were performed on a set of data created from groups of halfbrothers, from which groups with less than 20 animals were removed. The final data set for analysis consisted of 2055 records on bulls sired by 49 males. The numbers of bulls in half-brother groups are given in Tables 2 and 3.

The results obtained were analysed using the chi-square test of independence and the Fisher-Yates exact test.

\footnotetext{
*The Polish studies are generally related to phenotypic characteristics of conformation detects (Guliński et al., 2002; Stenzel et al., 2003; Wójcik et al., 2004).
} 
The chi-square test of independence is one of the most common methods for studying statistical relationships between categorical variables, but when the expected number is less than 5, this method may lead to inaccurate interpretation of results. When this is the case, the results have to be confirmed with the exact test for small counts. The Fisher-Yates exact test is one of the most popular tests used in practice.

Table 1. Incidence rate of morphological defects in the population of Polish Black-and-White Holstein-Friesian bulls

\begin{tabular}{l|c|c|c}
\hline \multirow{2}{*}{\multicolumn{1}{c}{ Type of defect }} & \multicolumn{3}{c}{ Incidence rate (\%) } \\
\cline { 2 - 4 } & no defect & minor defect & serious defect \\
\hline Heavy head & 99.90 & 0.10 & 0.00 \\
Short head & 99.95 & 0.05 & 0.00 \\
Short neck & 99.90 & 0.10 & 0.00 \\
Loose shoulders & 98.54 & 1.36 & 0.10 \\
Shallow chest & 99.76 & 0.24 & 0.00 \\
Narrow shoulders & 98.69 & 1.22 & 0.10 \\
Pendulous belly & 98.25 & 1.70 & 0.05 \\
Tucked-up belly & 99.66 & 0.34 & 0.00 \\
Swayed back & 98.05 & 1.90 & 0.05 \\
Roached back & 98.05 & 1.95 & 0.00 \\
Hip points projecting above dorsal line & 99.76 & 0.24 & 0.00 \\
Short pelvis & 99.81 & 0.19 & 0.00 \\
High tail head & 98.73 & 1.27 & 0.00 \\
Sunken anus & 99.95 & 0.05 & 0.00 \\
Sickle-hocked legs & 99.76 & 0.19 & 0.05 \\
Toeing out & 99.76 & 0.24 & 0.00 \\
Upright pastern & 98.35 & 1.56 & 0.10 \\
Soft pastern & 96.59 & 2.97 & 0.44 \\
Wide interdigital space & 90.32 & 7.49 & 2.19 \\
Heavy penis & 99.95 & 0.05 & 0.00 \\
Long scrotum & 99.71 & 0.29 & 0.00 \\
Testicular defects & 100.00 & 0.00 & 0.00 \\
MEANS & 98.79 & 1.07 & 0.14 \\
\hline & & & \\
\hline
\end{tabular}

This test is based on a Markov chain Monte Carlo simulation algorithm, which provides more accurate probability estimates when the number of samples has a count of 5 or less (Johnson, 1972).

The descriptive analyses, the chi-square test of independence and the FisherYates exact test were performed using the FREQ procedure of SAS. 
Table 2. Incidence rate and number of bulls with conformation defects sired by different males in population of Polish Black-and-White Holstein-Friesian bulls

\begin{tabular}{|c|c|c|c|c|c|c|c|c|c|}
\hline \multirow{3}{*}{$\begin{array}{l}\text { Number } \\
\text { of bull }\end{array}$} & \multirow{3}{*}{$\begin{array}{l}\text { Name } \\
\text { of bull }\end{array}$} & \multicolumn{8}{|c|}{ Number of defects } \\
\hline & & \multicolumn{2}{|c|}{ none } & \multicolumn{2}{|r|}{1} & \multicolumn{2}{|c|}{$2-3$} & \multicolumn{2}{|c|}{$4-5$} \\
\hline & & $\mathrm{n}$ & $\%$ & $\mathrm{n}$ & $\%$ & $\mathrm{n}$ & $\%$ & $\mathrm{n}$ & $\%$ \\
\hline 1 & 2 & 3 & 4 & 5 & 6 & 7 & 8 & 9 & 10 \\
\hline DE000578448776 & LAUDAN & 18 & 69.23 & 7 & 26.92 & 1 & 3.85 & 0 & 0.00 \\
\hline FR002998012650 & OKENDO & 52 & 77.61 & 11 & 16.42 & 4 & 5.97 & 0 & 0.00 \\
\hline PL000609159341 & RUDOLPH & 16 & 80.00 & 3 & 15.00 & 0 & 0.00 & 1 & 5.00 \\
\hline PL000609223245 & LEE & 35 & 89.74 & 2 & 5.13 & 2 & 5.13 & 0 & 0.00 \\
\hline PL000609285241 & OUTSIDE & 15 & 75.00 & 5 & 25.00 & 0 & 0.00 & 0 & 0.00 \\
\hline PL000609312745 & FESTIVAL & 12 & 60.00 & 2 & 10.00 & 5 & 25.00 & 1 & 5.00 \\
\hline PL000609353446 & CONVINCER & 15 & 53.57 & 8 & 28.57 & 5 & 17.86 & 0 & 0.00 \\
\hline PL000609353541 & LANTZ & 18 & 81.82 & 0 & 0.00 & 4 & 18.19 & 0 & 0.00 \\
\hline PL000609391145 & BRETT & 22 & 61.11 & 5 & 13.89 & 6 & 16.61 & 3 & 8.34 \\
\hline PL000609395846 & HERSHEL & 20 & 80.00 & 3 & 12.00 & 2 & 8.00 & 0 & 0.00 \\
\hline PL000609396840 & JESTHER & 37 & 60.66 & 17 & 27.87 & 6 & 9.84 & 1 & 1.64 \\
\hline PL000609438642 & MARSHALL & 51 & 75.00 & 10 & 14.71 & 6 & 8.82 & 1 & 1.47 \\
\hline PL000609438947 & INQUIRER & 47 & 74.60 & 12 & 19.05 & 4 & 6.35 & 0 & 0.00 \\
\hline PL000609439246 & MONDAY & 27 & 71.05 & 6 & 15.79 & 5 & 13.16 & 0 & 0.00 \\
\hline PL000609444144 & MANAT & 31 & 67.39 & 8 & 17.39 & 7 & 15.22 & 0 & 0.00 \\
\hline PL000609475747 & DOUTCH BOY & 37 & 84.09 & 7 & 15.91 & 0 & 0.00 & 0 & 0.00 \\
\hline PL000609487643 & МТОТО & 36 & 85.71 & 5 & 11.90 & 1 & 2.38 & 0 & 0.00 \\
\hline PL000609492246 & MERDRIGNAC & 24 & 88.89 & 3 & 11.11 & 0 & 0.00 & 0 & 0.00 \\
\hline PL000609496042 & GARTER & 44 & 78.57 & 10 & 17.86 & 2 & 3.57 & 0 & 0.00 \\
\hline PL000609497646 & STORMATIC & 57 & 91.94 & 5 & 8.06 & 0 & 0.00 & 0 & 0.00 \\
\hline PL000609511145 & MONZA & 20 & 90.91 & 2 & 9.09 & 0 & 0.00 & 0 & 0.00 \\
\hline PL000609512444 & OZZIE & 23 & 95.83 & 1 & 4.17 & 0 & 0.00 & 0 & 0.00 \\
\hline PL000609512549 & MACHOMAN & 36 & 94.74 & 1 & 2.63 & 1 & 2.63 & 0 & 0.00 \\
\hline PL000609521043 & MORTY & 49 & 80.33 & 11 & 18.03 & 1 & 1.64 & 0 & 0.00 \\
\hline PL000609541249 & FINLEY & 45 & 83.33 & 8 & 14.81 & 1 & 1.85 & 0 & 0.00 \\
\hline PL000609579345 & LANCELOT & 24 & 66.67 & 11 & 30.56 & 1 & 2.78 & 0 & 0.00 \\
\hline PL000609604946 & DAWSON & 40 & 72.73 & 13 & 23.64 & 2 & 3.64 & 0 & 0.00 \\
\hline PL000609605045 & LHEROS & 21 & 84.00 & 2 & 8.00 & 1 & 4.00 & 1 & 4.00 \\
\hline PL000609606144 & JUSTICE & 58 & 78.38 & 12 & 16.22 & 4 & 5.40 & 0 & 0.00 \\
\hline PL005020207602 & TUTOR & 31 & 86.11 & 4 & 11.11 & 1 & 2.78 & 0 & 0.00 \\
\hline PL005020208066 & HIGHWAY & 19 & 86.36 & 3 & 13.64 & 0 & 0.00 & 0 & 0.00 \\
\hline PL005034928757 & NIKO & 26 & 100.00 & 0 & 0.00 & 0 & 0.00 & 0 & 0.00 \\
\hline PL005053032503 & SAMBIA & 27 & 96.43 & 1 & 3.57 & 0 & 0.00 & 0 & 0.00 \\
\hline
\end{tabular}




\begin{tabular}{cll|r|r|r|r|r|r|r|r}
\hline \multicolumn{10}{c}{ Table 2 - contd. } \\
\hline 1 & \multicolumn{1}{c|}{2} & 3 & 4 & 5 & 6 & 7 & 8 & 9 & 10 \\
\hline PL005053309926 & ZETOR & 38 & 77.55 & 7 & 14.29 & 4 & 8.16 & 0 & 0.00 \\
PL005053310144 & CIAK & 21 & 87.50 & 3 & 12.50 & 0 & 0.00 & 0 & 0.00 \\
PL005053310373 & ZONK & 85 & 78.70 & 17 & 15.74 & 5 & 4.63 & 1 & 0.93 \\
PL005053310717 & PRECY & 23 & 92.00 & 1 & 4.00 & 1 & 4.00 & 0 & 0.00 \\
PL005053311325 & OURASI & 40 & 83.33 & 8 & 16.67 & 0 & 0.00 & 0 & 0.00 \\
PL005054463764 & BEST & 109 & 85.16 & 16 & 12.50 & 3 & 2.34 & 0 & 0.00 \\
PL005062430543 & JANKES & 24 & 85.71 & 3 & 10.71 & 1 & 3.57 & 0 & 0.00 \\
PL005074178648 & MEN & 31 & 91.18 & 3 & 8.82 & 0 & 0.00 & 0 & 0.00 \\
UK000100598172 & SHOTTLE & 18 & 81.82 & 4 & 18.18 & 0 & 0.00 & 0 & 0.00 \\
US000060000320 & GARRISON & 27 & 79.41 & 7 & 20.59 & 0 & 0.00 & 0 & 0.00 \\
US000120754720 & WIZARD & 25 & 86.21 & 3 & 10.34 & 1 & 3.45 & 0 & 0.00 \\
US000123066734 & TITANIC & 48 & 81.36 & 10 & 16.95 & 1 & 1.69 & 0 & 0.00 \\
US000123586443 & BOLIVER & 37 & 86.05 & 6 & 13.95 & 0 & 0.00 & 0 & 0.00 \\
US000125997863 & SOSA & 33 & 61.11 & 17 & 31.48 & 4 & 7.41 & 0 & 0.00 \\
US000128920633 & MURPHY & 34 & 91.89 & 2 & 5.41 & 1 & 2.70 & 0 & 0.00 \\
US000207124561 & MODEST & 19 & 86.36 & 2 & 9.09 & 1 & 4.55 & 0 & 0.00 \\
TOTAL & & 1645 & 80.05 & 307 & 14.94 & 94 & 4.57 & 9 & 0.44 \\
\hline
\end{tabular}

\section{Results}

Table 1 presents the incidence rate and severity of conformation defects in the bulls. The mean incidence of morphological defects was $1.21 \%$, including $0.14 \%$ of serious defects. In the analysed population of bulls, the only defect that did not occur was that of testes. The incidence of the other defective traits ranged from $0.05 \%$ to $9.68 \%$. The most frequent defects were those of legs: wide interdigital space $(9.69 \%$, including $2.19 \%$ classified as serious) and soft pastern (3.41\%, including $0.44 \%$ serious); and those of the back: swayed back ( $1.95 \%$, including $0.05 \%$ serious) and roached back (1.95\%). The least frequent defects were short head, sunken anus and heavy penis. The frequency of each of these traits was $0.05 \%$ on average.

Incidence rate and number of bulls with conformation defects with a division into groups of half-brothers, is presented in Table 2. In the analysed population, conformation defects were found in $19.95 \%$ of animals, including $14.94 \%$ of bulls with one defect, $4.57 \%$ of bulls with two or three defects, and $0.44 \%$ of animals with four or five conformation defects. The incidence and number of bulls with defects show large variation between different groups of half-brothers. The lowest incidence rate of number of bulls with conformation defects $(0-10 \%)$ was found in 9 groups. In 19 groups of half-brothers, this incidence rate of number of bulls ranged between 10 and $20 \%$. In 13 groups, it was in the $20-30 \%$ range. The highest incidence rate of the number of bulls with morphological defects $(30-50 \%)$ was found in 8 groups of half-brothers. 
Table 3. Phenotypic distribution of morphological defects in groups of half-brothers of PBWHF bulls

\begin{tabular}{|c|c|c|c|c|c|c|c|c|c|c|c|c|}
\hline Number of bull & Name of bull & 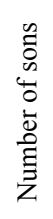 & 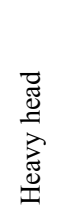 & 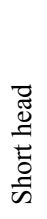 & 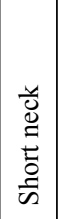 & $\begin{array}{l}\frac{0}{0} \\
\frac{0}{0} \\
\frac{0}{0} \\
\frac{0}{n} \\
0 \\
0 \\
0 \\
0\end{array}$ & 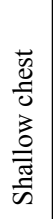 & 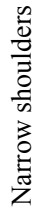 & 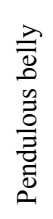 & 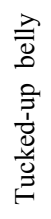 & 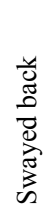 & 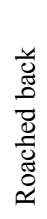 \\
\hline 1 & 2 & 3 & 4 & 5 & 6 & 7 & 8 & 9 & 10 & 11 & 12 & 13 \\
\hline DE000578448776 & LAUDAN & 26 & & & & & & & 1 & & & 3 \\
\hline FR002998012650 & OKENDO & 67 & & & & & & 1 & & 1 & 3 & \\
\hline PL000609159341 & RUDOLPH & 20 & & & & & & & & & & 1 \\
\hline PL000609223245 & LEE & 39 & & & & & 1 & 1 & & & & \\
\hline PL000609285241 & OUTSIDE & 20 & & & & & & & & & & 1 \\
\hline PL000609312745 & FESTIVAL & 20 & 1 & & & 2 & & 1 & & & & 3 \\
\hline PL000609353446 & CONVINCER & 28 & & & & 3 & & & 1 & & 2 & 1 \\
\hline PL000609353541 & LANTZ & 22 & & & & 2 & & & & & 3 & \\
\hline PL000609391145 & BRETT & 36 & & & 1 & 5 & & 3 & 1 & 1 & 1 & 1 \\
\hline PL000609395846 & HERSHEL & 25 & & & & & & & & & & \\
\hline PL000609396840 & JESTHER & 61 & & & 1 & 3 & & 1 & & 2 & & 2 \\
\hline PL000609438642 & MARSHALL & 68 & & & & 2 & 1 & & & 1 & 2 & 1 \\
\hline PL000609438947 & INQUIRER & 63 & & & & & & 1 & & & & 3 \\
\hline PL000609439246 & MONDAY & 38 & & & & & & 1 & 1 & & & \\
\hline PL000609444144 & MANAT & 46 & & & & 1 & 2 & 4 & & & 2 & 1 \\
\hline PL000609475747 & DOUTCH BOY & 44 & & & & & & & & & 1 & \\
\hline PL000609487643 & мTOTO & 42 & & & & & & & & & 1 & \\
\hline PL000609492246 & MERDRIGNAC & 27 & & & & & & & & 1 & & \\
\hline PL000609496042 & GARTER & 56 & & & & 3 & & & 1 & & 1 & \\
\hline PL000609497646 & STORMATIC & 62 & & & & & & & 1 & & 1 & \\
\hline PL000609511145 & MONZA & 22 & & & & & & & & & & \\
\hline PL000609512444 & OZZIE & 24 & & & & & & & & & 1 & \\
\hline PL000609512549 & MACHOMAN & 38 & 1 & & & & & & 1 & & 1 & \\
\hline PL000609521043 & MORTY & 61 & & 1 & & & & 2 & 1 & & 1 & \\
\hline PL000609541249 & FINLEY & 54 & & & & 1 & & & 1 & & 1 & \\
\hline PL000609579345 & LANCELOT & 36 & & & & & & & 1 & & & 1 \\
\hline PL000609604946 & DAWSON & 55 & & & & 1 & & 2 & & & & 2 \\
\hline PL000609605045 & LHEROS & 25 & & & & & & & 1 & & & 1 \\
\hline PL000609606144 & JUSTICE & 74 & & & & & & 1 & 2 & 1 & 1 & 1 \\
\hline PL005020207602 & TUTOR & 36 & & & & & & 1 & & & 1 & 1 \\
\hline PL005020208066 & HIGHWAY & 22 & & & & & & & 2 & & 1 & \\
\hline
\end{tabular}


Table 3 - contd

\begin{tabular}{|c|c|c|c|c|c|c|c|c|c|c|c|c|}
\hline 1 & 2 & 3 & 4 & 5 & 6 & 7 & 8 & 9 & 10 & 11 & 12 & 13 \\
\hline PL005034928757 & NIKO & 26 & & & & & & & & & & \\
\hline PL005053032503 & SAMBIA & 28 & & & & & & & & & & \\
\hline PL005053309926 & ZETOR & 49 & & & & 1 & & & 5 & & 3 & 1 \\
\hline PL005053310144 & CIAK & 24 & & & & & & & & & 1 & \\
\hline PL005053310373 & ZONK & 108 & & & & 2 & & 3 & 11 & & 1 & 4 \\
\hline PL005053310717 & PRECY & 25 & & & & & & & & & & 1 \\
\hline PL005053311325 & OURASI & 48 & & & & & & 1 & & & 1 & \\
\hline PL005054463764 & BEST & 128 & & & & 1 & & 2 & 1 & & 3 & 4 \\
\hline PL005062430543 & JANKES & 28 & & & & 1 & & & 1 & & 1 & 1 \\
\hline PL005074178648 & MEN & 34 & & & & & 1 & & & & & 1 \\
\hline UK000100598172 & SHOTTLE & 22 & & & & & & & & & & \\
\hline US000060000320 & GARRISON & 34 & & & & & & & & & & 2 \\
\hline US000120754720 & WIZARD & 29 & & & & & & & & & 1 & \\
\hline US000123066734 & TITANIC & 59 & & & & & & 1 & & & 4 & 1 \\
\hline US000123586443 & BOLIVER & 43 & & & & & & & & & & \\
\hline US000125997863 & SOSA & 54 & & & & 1 & & 1 & 2 & & 1 & 1 \\
\hline US000128920633 & MURPHY & 37 & & & & & & & & & & 1 \\
\hline US000207124561 & MODEST & 22 & & & & 1 & & & 1 & & & \\
\hline TOTAL & & 2055 & 2 & 1 & 2 & 30 & 5 & 27 & 36 & 7 & 40 & 40 \\
\hline \multicolumn{6}{|c|}{$\chi 2, \mathrm{~F}-\mathrm{Y} \quad(*-\mathrm{P} \leq 0.05, * *-\mathrm{P} \leq 0.01)$} & $* *$ & & & $* *$ & & & \\
\hline
\end{tabular}

Table 3 - contd.

\begin{tabular}{|c|c|c|c|c|c|c|c|c|c|c|c|c|c|c|}
\hline Number of bull & Name of bull & 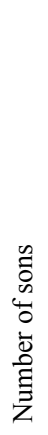 & 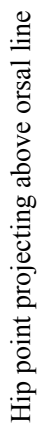 & 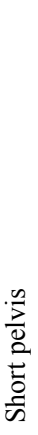 & 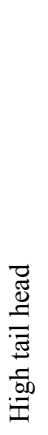 & 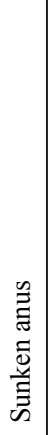 & 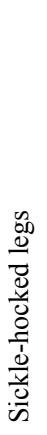 & 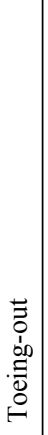 & 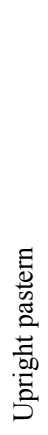 & 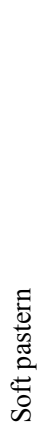 & 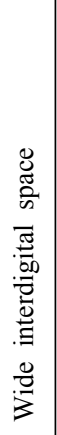 & 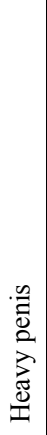 & $\begin{array}{l}\Xi \\
\Xi \\
0 \\
0 \\
0 \\
\infty \\
00 \\
0 \\
0 \\
\end{array}$ & 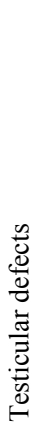 \\
\hline 1 & 2 & 3 & 4 & 5 & 6 & 7 & 8 & 9 & 10 & 11 & 12 & 13 & 14 & 15 \\
\hline DE000578448776 & LAUDAN & 26 & & & & & & & & 1 & 5 & & & \\
\hline FR002998012650 & OKENDO & 67 & & & & & & & & 5 & 9 & & & \\
\hline PL000609159341 & RUDOLPH & 20 & 2 & 1 & 1 & & & & & 1 & 1 & & & \\
\hline PL000609223245 & LEE & 39 & & 1 & & & & & 2 & & 1 & & & \\
\hline PL000609285241 & OUTSIDE & 20 & & & 1 & & & & 1 & & 2 & & & \\
\hline
\end{tabular}


Table 3 - contd.

\begin{tabular}{|c|c|c|c|c|c|c|c|c|c|c|c|c|c|c|}
\hline 1 & 2 & 3 & 4 & 5 & 6 & 7 & 8 & 9 & 10 & 11 & 12 & 13 & 14 & 15 \\
\hline PL000609312745 & FESTIVAL & 20 & & & 1 & & & & 1 & 3 & 5 & & & \\
\hline PL000609353446 & CONVINCER & 28 & 1 & & 1 & & 1 & & 2 & 1 & 5 & & & \\
\hline PL000609353541 & LANTZ & 22 & & & 1 & & & & & 1 & 2 & & & \\
\hline PL000609391145 & BRETT & 36 & 1 & & 3 & & & & 1 & 4 & 9 & & & \\
\hline PL000609395846 & HERSHEL & 25 & & & 1 & & & & & 2 & 5 & & & \\
\hline PL000609396840 & JESTHER & 61 & & & 2 & & & 1 & 1 & 4 & 17 & & & \\
\hline PL000609438642 & MARSHALL & 68 & & & 4 & & & 1 & 1 & 5 & 8 & & & \\
\hline PL000609438947 & INQUIRER & 63 & & 1 & & & & 1 & 1 & 3 & 9 & 1 & & \\
\hline PL000609439246 & MONDAY & 38 & & & & & 1 & & & 6 & 7 & & 1 & \\
\hline PL000609444144 & MANAT & 46 & & & 2 & & & & 2 & & 8 & & & \\
\hline PL000609475747 & DOUTCH BOY & 44 & & & & & & & & & 6 & & & \\
\hline PL000609487643 & мтото & 42 & & & 1 & & & & & 3 & 2 & & & \\
\hline PL000609492246 & MERDRIGNAC & 27 & & & & & & & & & 1 & & & \\
\hline PL000609496042 & GARTER & 56 & & & 2 & & & & 1 & 1 & 5 & & & \\
\hline PL000609497646 & STORMATIC & 62 & & & & & & & 1 & 1 & 1 & & & \\
\hline PL000609511145 & MONZA & 22 & & & & & & & 1 & & 1 & & & \\
\hline PL000609512444 & OZZIE & 24 & & & & & & & & & & & & \\
\hline PL000609512549 & MACHOMAN & 38 & & & & & & & & 1 & 7 & & & \\
\hline PL000609521043 & MORTY & 61 & & & & & & & 1 & 1 & 6 & & & \\
\hline PL000609541249 & FINLEY & 54 & 1 & & & & & & 1 & & 9 & & & \\
\hline PL000609579345 & LANCELOT & 36 & & & & & & & 2 & & 8 & & & \\
\hline PL000609604946 & DAWSON & 55 & & & & & & & 1 & 3 & 3 & & & \\
\hline PL000609605045 & LHEROS & 25 & & & 1 & & & & 1 & 1 & 6 & & & \\
\hline PL000609606144 & JUSTICE & 74 & & 1 & & & & & 1 & 7 & 2 & & & \\
\hline PL005020207602 & TUTOR & 36 & & & & & & & & 1 & & & & \\
\hline PL005020208066 & HIGHWAY & 22 & & & & & & & & & & & & \\
\hline PL005034928757 & NIKO & 26 & & & & & & & & & & & & \\
\hline PL005053032503 & SAMBIA & 28 & & & 1 & & & & & & & & & \\
\hline PL005053309926 & ZETOR & 49 & & & & & & & 1 & 1 & 4 & & & \\
\hline PL005053310144 & CIAK & 24 & & & & & & & & 1 & 1 & & & \\
\hline PL005053310373 & ZONK & 108 & & & & 1 & 1 & 1 & 3 & 2 & 2 & & & \\
\hline PL005053310717 & PRECY & 25 & & & & & & & & 1 & 1 & & 1 & \\
\hline PL005053311325 & OURASI & 48 & & & 1 & & & & 1 & 1 & 3 & & & \\
\hline PL005054463764 & BEST & 128 & & & 1 & & & & 3 & 2 & 3 & & 2 & \\
\hline PL005062430543 & JANKES & 28 & & & & & & & 1 & & & & & \\
\hline PL005074178648 & MEN & 34 & & & & & & & & & & & 1 & \\
\hline UK000100598172 & SHOTTLE & 22 & & & & & & & & & 4 & & & \\
\hline
\end{tabular}


Table 3 - contd.

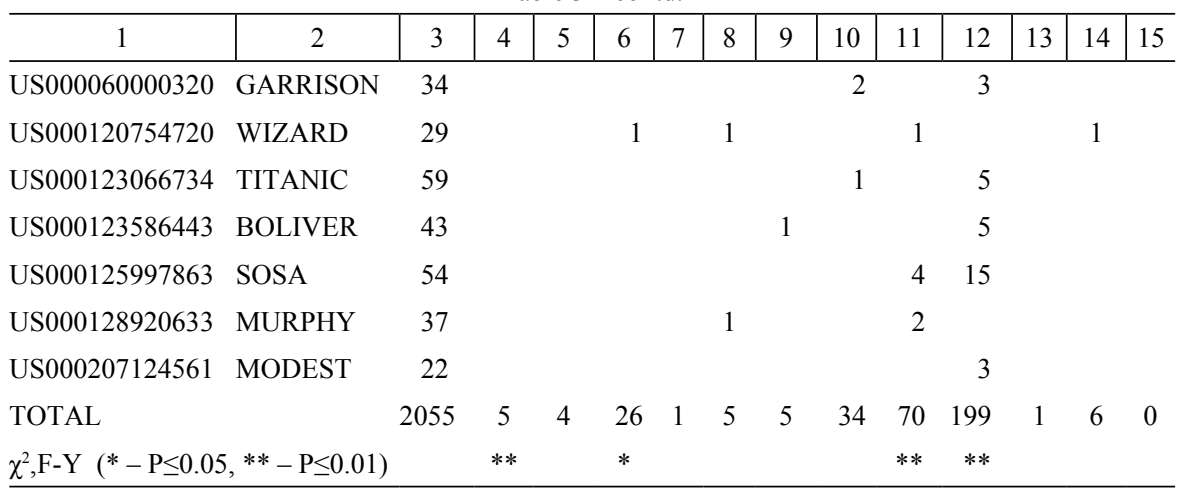

Table 3 gives the frequency of different conformation defects in bulls sired by different males, and in several cases the phenotypic distribution of conformation defects was confirmed with the chi-square test of independence and the Fisher-Yates exact test. The most common defects in the bull population analysed were two types of leg defects: wide interdigital space and soft pasterns, which occurred in 199 and 70 animals, respectively. Wide interdigital space was most frequent in 4 groups of half-brothers, in which this defect affected more than $25 \%$ of the bulls. This defect did not occur only in 9 groups of half-brothers. The third most frequent defect was upright pastern. This defect occurred in $1.65 \%$ of the population. In the analysed population, defects of the middle part of the body also formed a large group in terms of frequency. In this category, two defects were the most frequent: pendulous belly (36) and narrow shoulders (27). The phenotypic distribution of these defects was not confirmed by the tests.

\section{Discussion}

The frequency of external conformation traits in Polish Black-and-White Holstein-Friesian bulls is close to the frequency reported by Wang et al. (2002) for a Canadian population of Holstein-Friesian cows, which ranged from $0.09 \%$ to $11.94 \%$. Among defective traits analogous to those used to classify morphological defects in Polish bulls, one type of leg defect, i.e. coarse hock, was the most frequent. This defective trait affects $10.63 \%$ (1.31\% as a serious defect) of the Canadian HolsteinFriesian cow population on average.

It is worth noting the relatively high incidence of leg defects in our study, because both research and practical experience show that leg problems are one of the main reasons for culling in herds of Holstein-Friesian cattle and are detrimental in economic terms (Schneider et al., 2003; Booth et al., 2004; Cramer et al., 2009; Topolski and Jagusiak, 2010). Noteworthy in this context is the relatively high frequency of defects of the back and, among defects of the front, loose shoulders. In practice, bulls with loose shoulders and defects of the back, especially swayed back, are at risk of 
injury when stepping down from mounting. Once these injuries occur, the bulls fail to attempt further mounts, which makes it difficult or impossible to collect semen, resulting in the culling of these animals.

Of all defect categories, the least common defects were those of external genitalia (heavy penis and long scrotum), which were found in single animals. In the analysed population, the only defect that did not occur was that of testes.

The low frequency of the defects within categories mentioned above may result directly from selection work in the population of bulls chosen to be sires of the next generation, from which animals with this type of defects are eliminated. Before selection for the next stage of breeding, all young bulls are provisionally qualified based on veterinary examination, the main component of which is breeding soundness evaluation, in particular the conformation assessment of external genitalia.

It is particularly worth noting the differences in the frequency of conformation defects, especially leg defects, between groups of half-brothers. These differences indicate that selection of sires of bulls used for genetic improvement of Polish Blackand-White Holstein-Friesian cattle may to a certain extent determine the frequency of external conformation defects in the groups of sons sired by them. This is of major importance in breeding practice because mating combinations that account for the results of our study may help to eliminate external conformation defects from the Polish population of Holstein-Friesian cattle. These activities could be evaluated for effectiveness and optimized based on knowledge of the genetic parameters of conformation traits and the correlation of these traits with production and functional traits being improved in the population. Therefore, it is necessary in the future to make proper estimation of the genetic parameters of bull conformation defects, which is largely dependent on the properties of individual traits. The results obtained warrant further investigation in this area.

In conclusion, the present study showed a relatively high frequency of some conformation defects in the population of Polish Black-and-White Holstein-Friesian bulls, which are important from the economic and breeding point of view. In addition, the results obtained showed differences in the frequency of bull conformation defects between different groups of half-brothers. In the population of bulls that are actively used for reproduction in Poland, some groups of half-brothers exhibit a higher frequency of conformation defects than others. This fact is important for breeding practice because the results obtained could be used as an additional source of information during planning of matings, especially when selecting animals as sires of bulls. Our study also shows the need to estimate the genetic parameters of bull conformation defects, which would enable an optimum selection strategy to be developed.

\section{References}

B o e t t c her P., D e k kers J., W a r n i ck L., Wells S. (1998). Genetic analysis of clinical lameness in dairy cattle. J. Dairy Sci., 81: 1148-1156. 
B ooth C., Warnick L., Gröhn Y., Maizon D., Guard C., Janssen D. (2004). Effect of lameness on culling in dairy cows. J. Dairy Sci., 87: 4115-4122.

Brotherstone S., Mc Manus C., Hill W. (1990). Estimation of genetic parameters for linear type traits in Holstein-Friesian dairy cattle. Livest. Prod. Sci., 26: 177-192.

B u enger A., D u croc q V., Swalve H. (2001). Analysis of survival in dairy cows with supplementary data on type scores and housing systems from a region of Northwest Germany. J. Dairy Sci., 84: 1531-1541.

C a ravie 11 o D., W e ige 1 K., G i a nola D. (2004). Analysis of the relationship between type traits and functional survival in US Holstein cattle using a Weibull proportional hazards model. J. Dairy Sci., 87: 2677-2686.

Cramer G., Liss emore K., Guard C., Le sli e K., Kelt on D. (2009). The association between foot lesions and culling risk in Ontario Holstein cows. J. Dairy Sci., 92: 2572-2579.

Johnson E. (1972). The Fisher-Yates exact test and unequal sample sizes. Psychometrica, 37: $103-106$.

Guliński P., Litwińczuk Z., Dobrogowska E. (2002). Frequency of incidence of conformation defects in the Black-and-White dairy cows, kept in the individual farms of central-east Poland (in Polish). Zesz. Nauk. Prz. Hod., 62: 69-77.

S chneider M., D ürr J., C u e R., M on ardes H. (2003). Impact of type traits on functional herd life of Quebec Holsteins assessed by survival analysis. J. Dairy Sci., 86: 4083-4089.

S ewalem A., Kistemaker G., Miglior F., Van Doormaal B. (2004). Analysis of the relationship between type traits and functional survival in Canadian Holsteins using a Weibull proportional hazards model. J. Dairy Sci., 87: 3938-3946.

Stenzel R., Chabuz W., C i as tek K., Że lezik M, (2003). Frequency of incidence of conformation defects in primiparous cows at the Lubelskie region (in Polish). Zesz. Nauk. Prz. Hod., 68 (1): $355-362$.

Topolski P., Jagusiak W. (2010). Phenotypic characteristics of feet and leg type traits in Polish Black-and-White Holstein-Friesian bulls (in Polish). Rocz. Nauk. Zoot., 37: 105-114.

W a n g Y., S te ll a A., B o e t t c h e r P. (2002). Genetic analysis of defective type characteristics and their genetic relationships with herd life of Canadian Holsteins. J. Dairy Sci., 85: 457.e1-457.e9.

W ó j c i k P., Tre la J., M a j e w s k a A. (2004). Conformation defects in Black-and-White heifers (in Polish). Zesz. Nauk. Prz. Hod., 72: 323-328.

Accepted for printing 22 I 2012

PIOTR TOPOLSKI, WOJCIECH JAGUSIAK

Badania nad genetycznymi uwarunkowaniami wad pokroju w populacji buhajów rasy polskiej
holsztyńsko-fryzyjskiej odmiany czarno-bialej - analiza rozkładu fenotypowego

STRESZCZENIE

W literaturze specjalistycznej brak jest prac poświęconych zagadnieniom związanym z genetycznymi uwarunkowaniami wad pokroju buhajów bydła holsztyńsko-fryzyjskiego. Nielicznie prezentowane wyniki badań dotyczące tej tematyki obejmują wyłącznie żeńską część populacji. Biorąc pod uwagę priorytetowe znaczenie ścieżek ojcowskich w programach hodowlanych bydła mlecznego, a zwłaszcza ścieżki ojciec - syn, wskazane jest objęcie takimi analizami krajowej populacji buhajów hodowlanych. Badanie mechanizmu dziedziczenia cech poprzez porównawczą analizę rozkładu fenotypów rodziców i potomstwa jest podstawowym sposobem zdobywania wiedzy o ich genetycznych uwarunkowaniach. W ramach badań analizowano rozkład fenotypowy 22 rutynowo ocenianych wad pokroju w populacji buhajów rasy polskiej holsztyńsko-fryzyjskiej odmiany czarno-białej, pochodzących po różnych ojcach. Wykazano zmienność w średniej frekwencji występowania poszczególnych wad budowy zewnętrznej 
i stopniu ich nasilenia. Stwierdzono duże zróżnicowanie w częstości występowania wad pokroju oraz ich liczbie pomiędzy grupami półbraci. Dominującymi defektami w analizowanej populacji buhajów są dwa rodzaje wad kończyn: zbyt szeroka szpara racicy oraz miękka pęcina, które wystąpiły odpowiednio u 199 i 70 osobników. W przypadku pierwszej z wymienionych cech stwierdzono wyraźną dominację jej częstości w 4 grupach półbraci, w obrębie których buhaje z tym rodzajem defektu stanowiły powyżej $25 \%$. Najrzadziej występującymi wadami były defekty zewnętrznych narządów rozrodczych, które odnotowano u pojedynczych osobników. Nie stwierdzono występowania jedynie jednej cechy - wady jąder. Statystyczną istotność uzyskanych rozkładów fenotypowych wad pokroju buhajów potwierdzono testem niezależności chi-kwadrat i testem dokładności Fishera-Yatesa. Otrzymane wyniki świadczą także o możliwości podjęcia badań nad oszacowaniem parametrów genetycznych wad pokroju buhajów, których znajomość pozwoliłaby na opracowanie optymalnej strategii selekcji w krajowej populacji bydła holsztyńsko-fryzyjskiego. 